\title{
Economic Implications of Thermal Energy Storage for Concentrated Solar Thermal Power
}

\author{
Sharon J. Wagner ${ }^{1 *}$, Edward S. Rubin ${ }^{1}$ \\ ${ }^{1}$ Carnegie Mellon University, Pittsburgh, PA, United States of America \\ * Corresponding author. Tel: +1 412592 6986,E-mail: sjwagner@andrew.cmu.edu
}

\begin{abstract}
A 110-MW parabolic trough power plant operating in California was modeled to observe the effect of molten salt thermal energy storage capacity on plant performance, cost, and profitability. A plant with no storage (PT-NG) was modeled to match the hourly and annual electricity output of a comparable plant with storage (PT-TES). The solar field area for the PT-TES plant was selected to minimize the unsubsidized levelized cost of electricity (LCOE). For each storage capacity modeled here (1-12 hours), PT-NG resulted in a larger solar field area and higher O\&M costs than the respective PT-TES option. PT-TES generally had higher capital costs than PT-NG, and the PT-NG levelized cost of electricity (LCOE) varied from 6\% higher compared with smaller TES capacities to $6 \%$ less compared with larger TES capacities. T he profitability of PT-NG compared to PT-TES followed a similar trend to the LCOE with larger margins of difference in select scenarios. These results were achieved with $3-22 \%$ of the net electric output from natural gas in the PT-NG plant. The $30 \%$ investment tax credit (ITC), currently in place for solar energy in the United States, lowered the capital costs and LCOE for each configuration. Electricity pricing through a power purchase agreement (PPA) of \$200/MWh was more profitable than hourly real-time electricity pricing, which resulted in a net annual loss for all configurations. B oth the PPA and ITC were required to achieve a positive annual profit, and the maximum annual profit achieved was \$US 11 million per year with 0 hours of storage.
\end{abstract}

Keywords: concentrated solar power, thermal storage

\section{Nomenclature}

$Q \quad$ thermal energy......................................

M mass ................................................ kg

$T$ temperature ......................................... ${ }^{\circ} \mathrm{C}$

$K$ piping thermal losses......................... $\mathrm{J} / \mathrm{m}^{2}$

$T_{o}$ ambient temperature ............................... ${ }^{\circ} \mathrm{C}$

$L \quad$ length of pipe in solar field....................... $m$

$l_{\text {gap }}$ length of gap between solar collector assemblies (SCA) ........................................ $m$

$w_{\text {sca }}$ SCA width ................................................. $m$

$l_{b r} \quad$ length of space between SCA rows........... $m$

$A_{S C A} S C A$ aperture area ................................... $\mathrm{m}^{2}$

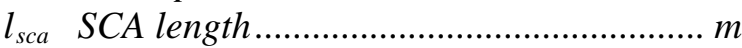

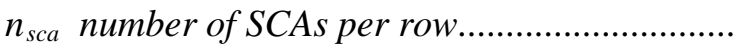

$\theta \quad$ incidence angle .............................................

$\eta_{\text {opt }}$ SCA optical efficiency.

IAM incidence angle modifier

$F_{s}$ mirror soiling factor.

$d_{o} \quad$ outer diameter of solar field pipe ............. $m$

$\mathrm{m}$ mass flow rate ...................................... kg/s

$\Delta h$ enthalpy change ....................................... J/s

$t \quad$ hour of TES storage capacity ................. hrs

$h_{i} \quad$ enthalpy at inlet ...................................... J/s $h_{e} \quad$ enthalpy at exit ......................................... J/s

$\eta \quad$ efficiency or effectiveness..............................

$h_{e s}$ enthalpy of isentropic state at exit ......... J/s

$w$ work per unit mass .......................... J/kg•s

$W$ power ................................................... J/s

Cp specific heat .................................. J/kg

$r \quad$ density ........................................... $\mathrm{kg} / \mathrm{m}^{3}$

CF plant capacity factor ............................... \%

$W_{\text {tdesign }}$ design turbine output ........................ MJ

$D_{\text {htr }}$ natural gas-fired heater heat duty...... MJ/hr

$k \quad$ loan interest rate ..................................... \%

$j \quad$ loan lifetime ..........................................years

C cost .............................................\$US2009

i discount rate ........................................... \%

n plant lifetime ...........................................years

$F_{\text {debt }}$ debt portion of capital cost ................... \%

$F_{\text {equity }}$ equity portion of capital cost ............... \%

NPV net present value .......................................\$

LAC levelized annual capital cost .............. \$ $\$ y r$

$C_{O M}$ annual operation and maintenance cost $\$ / y r$

$p \quad$ price of electricity ..........................\$/MWh

\section{Introduction}

Solar energy is an attractive renewable energy source because the sun's energy is plentiful and carbon-free. Cost and intermittency issues have prevented widespread deployment of 
solar power plants, but these issues may be partially mitigated with the addition of thermal energy storage (TES). Molten salt TES can be used in lieu of a natural gas boiler to provide backup energy for a parabolic trough concentrated solar thermal power (PT) plant during cloudy periods and nighttime. TES can enable a PT plant to provide reliable peak or baseload electricity without sacrificing carbon neutrality by relying on a natural gas backup system. However, the additional equipment associated with a TES system can add substantially to the already high capital cost of PT. An investor will only accept the additional cost of these components if the potential exists for an economic benefit that exceeds the extra cost. This study examines the economic implications of TES through an engineering-economic model. The model calculates the levelized cost of electricity and expected annual profit of a PT plant with varying TES capacities and compares these results to a similar PT plant with natural gas backup.

\section{Methodology}

An engineering-economic model was developed to simulate the hourly and annual performance and cost of a PT plant. A visual representation of the engineering portion of this model is presented in Figure 1. Typical meteorological year (TMY3) direct normal radiation (DNR) and ambient temperature data for Daggett, California [1] were used as inputs to a series of component-based mass and energy balances to simulate the thermodynamic operation of the system. Two separate and distinct engineering models were created: 1) PTTES, which models a PT plant that uses a TES system, and 2) PT-NG, which models a plant that uses a natural gas-fired heat transfer fluid (HTF) heater in place of a TES system.

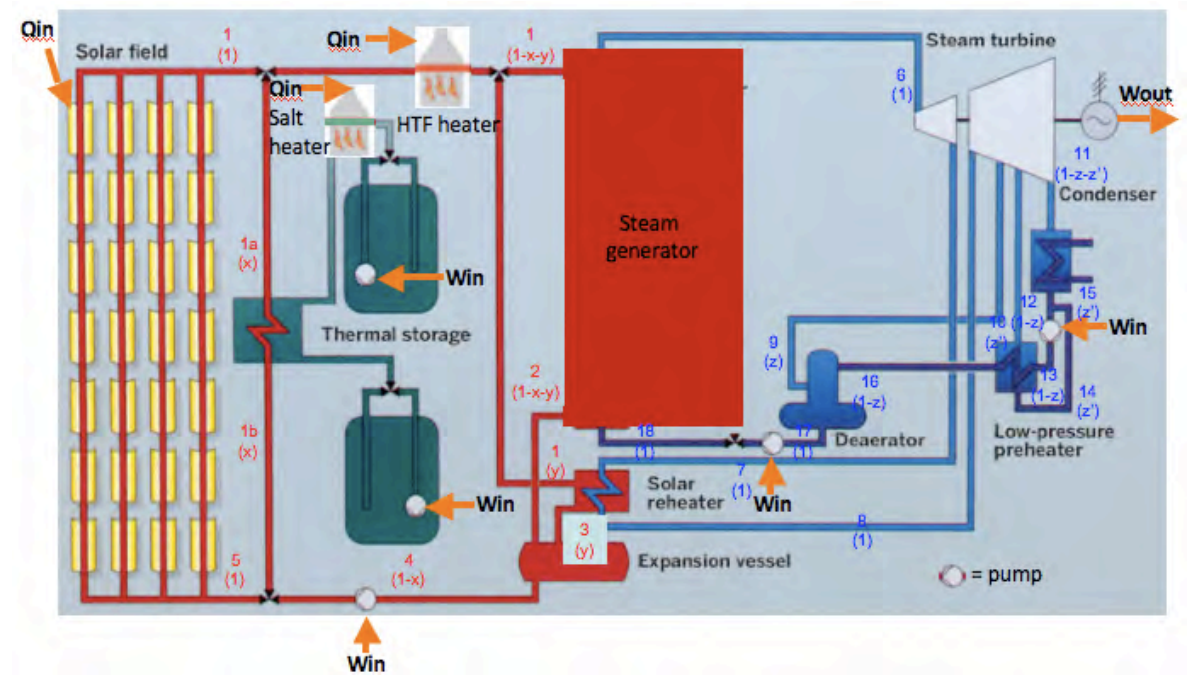

Fig. 1. Parabolic Trough Plant Schematic (adapted from [2]).

Hourly DNR enters the solar field and is concentrated on the heat transfer fluid (HTF) in the receiver tubes (red). The HTF is pumped to the power cycle where energy is transferred to steam (blue) via the steam generator and reheater. The heat from the steam drives the turbines to generate power (Wout) and the cooled HTF returns to the solar field. When the TES system is charging, some HTF flows to the heat exchanger to transfer energy to molten salt. Hot salt is stored in one tank and cold salt in the other. When the ambient temperature threatens to freeze the salt, the salt heater is activated to maintain the temperature above freezing. The HTF heater is used to maintain the HTF temperature above freezing when altering the HTF mass flow rate fails to prevent freezing. The HTF heater is used as an alternative to the TES system in the PT-NG plant. The heat energy input to the two heaters from natural gas combustion is represented as Qin. Five pumps are used in the system, and the work required to operate them is shown as Win. Red numbers refer to HTF states, blue numbers refer to steam states, and numbers in parentheses represent mass flow fractions. 
The PT-TES model incorporates seven distinct operation modes, which are presented in Table 1. The hourly simulation selects operation modes based on whether all criteria are satisfied, following the hierarchy shown in Table 1. For example, if Day_TESC fails, the simulation will attempt to run Day_SOLAR. If Day SOLAR fails, the simulation will attempt Day_TESD, and so on. T he PT-NG model only uses Day_SOLAR, Night_SD, and Night_FP, and incorporates an additional mode similar to Day_TESD that uses the HTF heater in place of the TES system. The PT-NG model uses as inputs the $\mathrm{T}_{1}, \mathrm{~W}_{\text {net }}$, and $\mathrm{W}_{\text {sold }}$ results from the PT-TES model (see equations 30 and 31), and the solar field area for PT-NG is selected to minimize the difference between $\mathrm{W}_{\text {sold }}$ from each model, in order to simulate two different power plants that generate comparable amounts of hourly and annual electricity.

Table 1. Plant operation modes.

\begin{tabular}{|c|c|c|}
\hline Mode ID & Description & Criteria \\
\hline Day_TESC & $\begin{array}{l}\text { Only the solar field delivers thermal energy to the power } \\
\text { cycle; excess solar energy "charges" the TES system }\end{array}$ & $\begin{array}{l}\mathrm{Q}_{\mathrm{SF}}>\min \\
\mathrm{M}_{\mathrm{salt}}<\max \end{array}$ \\
\hline Day_SOLAR & $\begin{array}{l}\text { Only the solar field delivers thermal energy to the power } \\
\text { cycle; the TES system is idle }\end{array}$ & $\begin{array}{l}0<\mathrm{Q}_{\mathrm{SF}} \leq \min \\
\mathrm{M}_{\mathrm{salt}} \leq \min \end{array}$ \\
\hline Day_TESD & $\begin{array}{l}\text { The solar field and the TES system deliver thermal energy } \\
\text { to the power cycle }\end{array}$ & $\begin{array}{l}0<\mathrm{Q}_{\mathrm{SF}}<\min \\
\mathrm{M}_{\text {salt }}>\min \end{array}$ \\
\hline Night_TESD & $\begin{array}{l}\text { Only the TES system delivers thermal energy to the } \\
\text { power cycle; HTF circulates through the solar field at a } \\
\text { minimum mass flow rate to stay warm }\end{array}$ & $\begin{array}{l}\mathrm{Q}_{\mathrm{SF}} \leq 0 \\
\mathrm{M}_{\text {salt }}>\min \end{array}$ \\
\hline Night_SD & $\begin{array}{l}\text { The power cycle is idle; HTF circulates through the solar } \\
\text { field at a minimum mass flow rate to stay warm }\end{array}$ & $\begin{array}{l}\mathrm{Q}_{\mathrm{SF}} \leq 0 \\
\mathrm{M}_{\text {salt }} \leq \min \end{array}$ \\
\hline Night_TESFP & $\begin{array}{l}\text { The power cycle is idle; HTF circulates through the solar } \\
\text { field at a minimum mass flow rate, and the TES system } \\
\text { protects the HTF from freezing }\end{array}$ & $\begin{array}{l}\mathrm{Q}_{\mathrm{SF}} \leq 0 \\
\mathrm{M}_{\text {salt }}>\min \\
\mathrm{T}_{\mathrm{HTF}} \leq \min \end{array}$ \\
\hline Night_FP & $\begin{array}{l}\text { The power cycle is idle; HTF circulates through the solar } \\
\text { field at a minimum mass flow rate, and the natural gas- } \\
\text { fired heater protects the HTF from freezing }\end{array}$ & $\begin{array}{l}\mathrm{Q}_{\mathrm{SF}} \leq 0 \\
\mathrm{M}_{\text {salt }} \leq \min \\
\mathrm{T}_{\mathrm{HTF}} \leq \min \end{array}$ \\
\hline
\end{tabular}

The hourly simulation uses an iterative process that selects an operation mode based on the net energy captured by the solar field $\left(\mathrm{Q}_{\mathrm{SF}}\right)$, the total mass of salt in the "hot" TES tank $\left(\mathrm{M}_{\text {salt }}\right)$, and the temperature of the HTF. The minimum $\mathrm{Q}_{\mathrm{SF}}$ for the 110-megawatt (MW) system modeled here is 245 megawatt-hours $(\mathrm{MWh})$. The hourly $\mathrm{Q}_{\mathrm{SF}}$ value depends on hourly ambient conditions and HTF temperature, as shown in equations 1 through 3 . T he solar field area (A) is specified at the beginning of each simulation and varied to achieve the lowest levelized cost of electricity (LCOE). E quation 2 is a simplified version of the calculation used to determine the length of pipe in the solar field, which is a required input to equation 3 .

$\mathrm{K}=\mathrm{a}+\mathrm{b} \cdot\left(\mathrm{T}_{\mathrm{HTF}}-\mathrm{T}_{\mathrm{o}}\right)+\mathrm{c} \cdot\left(\mathrm{T}_{\mathrm{HTF}}-\mathrm{T}_{\mathrm{o}}\right)^{2}$

where $a, b$, and c are empirical thermal loss coefficients [3]

$$
\begin{aligned}
& \mathrm{L}=1_{\text {gap }}+2 \cdot \mathrm{w}_{\mathrm{sca}}+2 \cdot 1_{\mathrm{br}}+\left(\mathrm{A} \div \mathrm{A}_{\mathrm{SCA}}\right) \cdot\left(\left(1_{\mathrm{sca}} \bullet \mathrm{w}_{\mathrm{sca}}-\mathrm{A}_{\mathrm{SCA}}\right) \div \mathrm{w}_{\mathrm{sca}}+1_{\mathrm{sca}}+1_{\mathrm{br}} \div\left(\mathrm{A}_{\mathrm{SCA}} \bullet \mathrm{n}_{\mathrm{sca}}\right)+\right. \\
& \left.\quad\left(2 \cdot \mathrm{w}_{\mathrm{sca}}+2 \cdot 1_{\mathrm{br}}\right) \div \mathrm{n}_{\mathrm{sca}}-\left(2 \cdot \mathrm{A}_{\mathrm{SCA}} \cdot\left(\mathrm{w}_{\mathrm{sca}}+\mathrm{l}_{\mathrm{br}}\right)\right) / \mathrm{A}\right) \\
& \mathrm{Q}_{\mathrm{SF}}=\mathrm{A} \cdot \mathrm{DNR} \cdot \cos (\theta) \cdot \eta_{\mathrm{opt}} \cdot \mathrm{IAM} \cdot \mathrm{F}_{\mathrm{s}}-\mathrm{K} \cdot \pi \cdot \mathrm{d}_{\mathrm{o}} \cdot \mathrm{L} \cdot\left(\mathrm{T}_{\mathrm{HTF}}-\mathrm{T}_{\mathrm{o}}\right)
\end{aligned}
$$

where $l_{\text {gap }}=1 \mathrm{~m}, w_{\text {sca }}=5.77 \mathrm{~m}, l_{\text {br }}=15 \mathrm{~m}, A_{S C A}=817.5 \mathrm{~m}^{2}, l_{\text {sca }}=149 \mathrm{~m}, n_{s c a}=4, d_{o}=0.07 \mathrm{~m}$, and $\eta_{\text {opt }}=82 \%$ [3] 
Equation 4 shows how the model calculates the total amount of $\mathrm{M}_{\text {salt }}$ using the design values presented in [4]. The HTF factor $\left(\mathrm{F}_{\mathrm{HTF}}\right)$ was selected as 1.5 after several iterations of the model indicated that the hourly $\mathrm{m}_{\mathrm{HTF}}$ rarely exceeded 1.5 times the design value. The number of hours of TES capacity refers to the number of hours the turbine could operate at full rated capacity using only the thermal energy from the storage system. The extra salt factor $\left(\mathrm{F}_{\text {salt }}\right)$ represents the amount of salt that must remain in the TES tanks at all times. In this study, the nominal value for $\mathrm{F}_{\text {salt }}$ was 1.14 [4].

$\mathrm{M}_{\text {salt }}=-\left(\left(3600 \bullet\left(\mathrm{m}_{\mathrm{HTF}}-\mathrm{m}_{\mathrm{HTFo}}\right) \cdot \mathrm{F}_{\mathrm{HTF}} \bullet\left(\Delta \mathrm{h}_{\mathrm{HTF}}\right)\right) \cdot \mathrm{t} \cdot \mathrm{F}_{\text {salt }}\right) /\left(\Delta \mathrm{h}_{\text {salt }}\right)$

where $m_{\text {HTF }}=1,206 \mathrm{~kg} / \mathrm{s}, m_{\text {HTFo }}=121 \mathrm{~kg} / \mathrm{s}, F_{\text {HTF }}=1.5, F_{\text {salt }}=1.14$

The model calculates the design states and mass flow rates of all fluids in the system shown in Figure 1 through a series of component mass and energy balance equations based on the First Law of Thermodynamics, assuming steady-state conditions and zero kinetic or potential energy flows (equations 5-29). The key design inputs to these equations include: $\mathrm{T}_{1}=393^{\circ} \mathrm{C}$, $\mathrm{T}_{3}=225{ }^{\circ} \mathrm{C}, \mathrm{T}_{5}=293{ }^{\circ} \mathrm{C}, \mathrm{T}_{6}=373{ }^{\circ} \mathrm{C}$, pressure $(\mathrm{p})_{4}=110 \mathrm{kPa}, \mathrm{p}_{5}=620 \mathrm{kPa}, \mathrm{p}_{6}=10,001$ $\mathrm{kPa}, \mathrm{p}_{7}=1,900 \mathrm{kPa}, \mathrm{p}_{8}=1,700 \mathrm{kPa}, \mathrm{p}_{9}=700 \mathrm{kPa}, \mathrm{p}_{11}=8 \mathrm{kPa}, \mathrm{p}_{12}=200 \mathrm{kPa}, \mathrm{p}_{18}=10,200$ $\mathrm{kPa}, \eta_{\text {turbine }}=85 \%, \eta_{\text {pump }}=80 \%, \eta_{\text {preheater }}=80 \%$, TES heat exchanger effectiveness of heating and cooling $=88 \%$. The hourly simulation also uses equations 5-29 to set the hourly states, beginning with a starting $\mathrm{T}_{5}$ value of $100{ }^{\circ} \mathrm{C}$.

Heat exchangers (steam generator/ reheater, condenser, LP preheater, TES heat exchanger, salt \& HTF heaters):

$\mathrm{h}_{\mathrm{i}}=\left(\eta \cdot \mathrm{h}_{\mathrm{es}}-\mathrm{h}_{\mathrm{e}}\right) \div(\eta-1)$

$\mathrm{h}_{\mathrm{e}}=\mathrm{h}_{\mathrm{i}}+\eta \cdot\left(\mathrm{h}_{\mathrm{es}}-\mathrm{h}_{\mathrm{i}}\right)$

$\mathrm{h}_{\mathrm{e}}=\mathrm{h}_{\mathrm{i}}+\left(\mathrm{m}_{\text {steam }} \cdot\left(\mathrm{h}_{\mathrm{i} \_ \text {steam }}-\mathrm{h}_{\mathrm{e} \_ \text {steam }}\right)\right) \div \mathrm{m}_{\text {HTFadj }}$

$\mathrm{Q}=\mathrm{m} \cdot(\Delta \mathrm{h}) \cdot 3600$

where, $\eta=$ heat exchanger effectiveness, adj = mass flow rate adjusted with fractions shown in Fig. 1

Turbines:

$\mathrm{w}=\eta \cdot\left(\mathrm{h}_{\mathrm{i}}-\mathrm{h}_{\mathrm{es}}\right)$

$\mathrm{h}_{\mathrm{e}}=\mathrm{h}_{\mathrm{i}}-\mathrm{w}$

$\mathrm{W}=\mathrm{w} \cdot \mathrm{m}_{\text {steam }}$

Rankine cycle pumps:

$\mathrm{w}=\left(\mathrm{h}_{\mathrm{i}}-\mathrm{h}_{\mathrm{es}}\right) \div \eta$

$\mathrm{h}_{\mathrm{e}}=\mathrm{h}_{\mathrm{i}}-\mathrm{w}$

$\mathrm{W}=\mathrm{W} \cdot \mathrm{m}_{\text {steam }}$

Expansion vessel:

$\mathrm{h}_{4}=(1-\mathrm{y}) \cdot \mathrm{h}_{2}+\mathrm{y} \cdot \mathrm{h}_{3}$

Solar field pump:

$\mathrm{W}=\mathrm{m}_{\mathrm{HTF}} *\left(\mathrm{r}_{4}^{-1} *\left(\mathrm{p}_{4}-\mathrm{p}_{5}\right) \div \eta\right)$

$\mathrm{h}_{5}=\mathrm{h}_{4}-\mathrm{w}$

Mass flow rates and fractions:

$\mathrm{z}=\left(\mathrm{h}_{17}-\mathrm{h}_{16}\right) \div\left(\mathrm{h}_{9}-\mathrm{h}_{16}\right)$

$\mathrm{z}^{\prime}=\left(\mathrm{z} \cdot\left(\mathrm{h}_{16}-\mathrm{h}_{14}\right)+\mathrm{h}_{14}-\mathrm{h}_{16}\right) \div\left(\mathrm{h}_{14}-\mathrm{h}_{12}\right)$ 


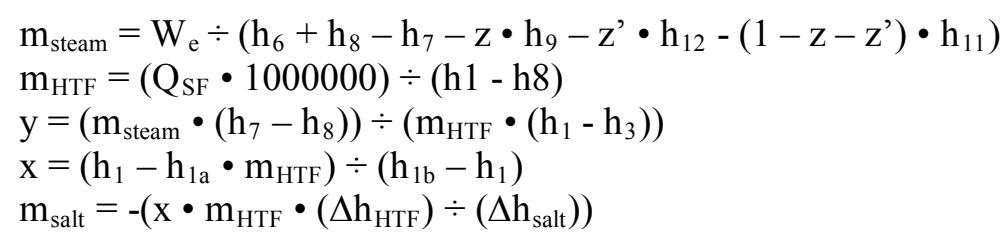

Therminol VP-1 (HTF) and nitrate salt properties [5]:

$\mathrm{Cp}_{\mathrm{HTF}}=7.888 \mathrm{e}-4 \cdot \mathrm{T}^{2}+2.496 \cdot \mathrm{T}+1.509 \mathrm{e} 3$

$\mathrm{Cp}_{\text {salt }}=1.72 \mathrm{e}-1 \cdot \mathrm{T}+1.443 \mathrm{e} 3$

$\mathrm{h}_{\mathrm{HTF}}=1.377 \cdot \mathrm{T}^{2}+1.498 \mathrm{e} 3 \cdot \mathrm{T}-1.834 \mathrm{e} 4$

$\mathrm{h}_{\text {salt }}=8.6 \mathrm{e}-2 \cdot \mathrm{T}^{2}+1.443 \mathrm{e} 3 \cdot \mathrm{T}$

$\mathrm{r}_{\mathrm{HTF}}=-7.762 \mathrm{e}-4 \cdot \mathrm{T}^{2}-6.367 \mathrm{e}-1 \cdot \mathrm{T}+1.0740 \mathrm{e} 3$

The net electricity generated by the system is calculated using equation 30 , and then separated into electricity sold and bought (equations 31 and 32) for the cost model. The power losses due to auxiliary equipment such as electronic motors, drives, computers, etc ( $\left.\mathrm{W}_{\text {aux }}\right)$ are calculated using the series of equations described in [6]. Equation 33 calculates the capacity factor based on electricity sold, while equation 34 calculates capacity factor based on net electricity generated (after subtracting electricity used by pumps during nighttime hours).

$$
\begin{gathered}
\mathrm{W}_{\text {net }}=\mathrm{W}_{\text {turbines }}-\mathrm{W}_{\text {pumps }}-\mathrm{W}_{\text {aux }} \\
\mathrm{W}_{\text {sold }}=\mathrm{W}_{\text {net }} \text { when } \mathrm{W}_{\text {net }}>0 \\
\mathrm{~W}_{\text {bought }}=\text { abs }\left(\mathrm{W}_{\text {net }}\right) \text { when } \mathrm{W}_{\text {net }}<0 \\
\mathrm{CF}=\mathrm{W}_{\text {sold }} \div\left(\mathrm{W}_{\text {tdesign }} \cdot 8760\right) \\
\quad(33) \\
\mathrm{CF}_{\text {net }}=\mathrm{W}_{\text {net }} \div\left(\mathrm{W}_{\text {tdesign }} \cdot 8760\right)
\end{gathered}
$$

where $W_{\text {aux }}$ refers to power losses through auxiliary loads

The economic model calculates the total capital cost of the plant and the annual operation and maintenance (O\&M) costs using a slightly adapted version of the National Renewable Energy Laboratory's (NREL) Solar Advisor Model (SAM) cost model [7], which was developed for a plant with a solar field area of $854,000 \mathrm{~m}^{2}$. In order to apply this model to a variety of solar field sizes, a scaling factor (the ratio of the solar field area to the reference solar field area) is used for area-dependent O\&M cost items. Calculations were added for the capital cost of the HTF and salt heaters as well (equations 35 and 36).

$\mathrm{D}_{\mathrm{htr}}=\left(\max \left(\mathrm{Q}_{\mathrm{htr}}\right) \bullet 0.00094781712\right) \div 1000000$

$\mathrm{C}_{\mathrm{htr}}=13402 \cdot \mathrm{D}_{\mathrm{htr}}+367158$

The levelized cost of electricity (LCOE) is calculated using equations 37-40. An alternative, subsidized levelized annual capital cost (LAC) is also calculated with the current United States federal investment tax credit (ITC) for solar energy investments. This ITC is applied as a cash grant, i.e., a deduction, of $30 \%$ of the total plant capital cost.

$$
\begin{aligned}
& \mathrm{C}_{\text {loan }}=\left(\mathrm{k} \div\left(1-(1+\mathrm{k})^{-\mathrm{j}}\right)\right) \cdot \mathrm{C}_{\text {cap }} \cdot \mathrm{F}_{\text {debt }} \\
& \mathrm{NPV}_{\text {loan }}=\Sigma\left(\mathrm{C}_{\text {loan }} \div\left((1+\mathrm{i})^{\text {year }}\right)\right) \\
& \mathrm{LAC}=\left(\mathrm{i} \div\left(1-(1+\mathrm{i})^{-\mathrm{n}}\right)\right) \cdot\left(\mathrm{NPV}_{\text {loan }}+\mathrm{C}_{\text {cap }} \cdot \mathrm{F}_{\text {equity }}\right) \\
& \mathrm{LCOE}=\left(\mathrm{LAC}+\mathrm{C}_{\mathrm{OM}}\right) \div \mathrm{W}_{\text {sold }}
\end{aligned}
$$

The expected annual profit $(\mathrm{P})$ is calculated using equation 41 and hourly historic electricity pricing data from the California Independent System Operator (CAISO) from 2008 [8]. This calculation assumes that the power plant receives the real-time price of electricity from the 
CAISO. An alternative $\mathrm{P}$ is calculated under the assumption that the plant owner enters into a power purchase agreement (PPA), and this calculation is shown as equation 42 .

$\mathrm{P}=\Sigma\left(\mathrm{W}_{\text {sold }} \cdot(\mathrm{p}-\mathrm{LCOE})\right)$

$\mathrm{P}_{\mathrm{PPA}}=\Sigma\left(\mathrm{W}_{\text {sold }} \cdot\left(\mathrm{p}_{\mathrm{PPA}}-\mathrm{LCOE}\right)\right)$

\section{Results}

The solar field area for PT-TES was selected to minimize the LCOE, while the solar field area for PT-NG was selected to minimize the difference between $\mathrm{W}_{\text {sold }}$ in the two models. Figure 2 shows that the solar field area increased with increasing storage capacities in order to capture enough energy for the TES system. The solar field area for the PT-NG plant increased even more because it was required to meet the hourly solar-generated electricity output of the PT-TES plant without being able to store excess solar energy during high DNR hours. The capacity factor for each plant was almost identical since PT-NG was designed to match PT-TES. The net capacity factor for each system was smaller because it subtracts nighttime pump energy from the annual electricity generation. O verall, capacity factor increased with storage capacity as the plants operated for more annual hours. The PT-NG plant generated $3-22 \%$ of its annual electricity with the NG heater.
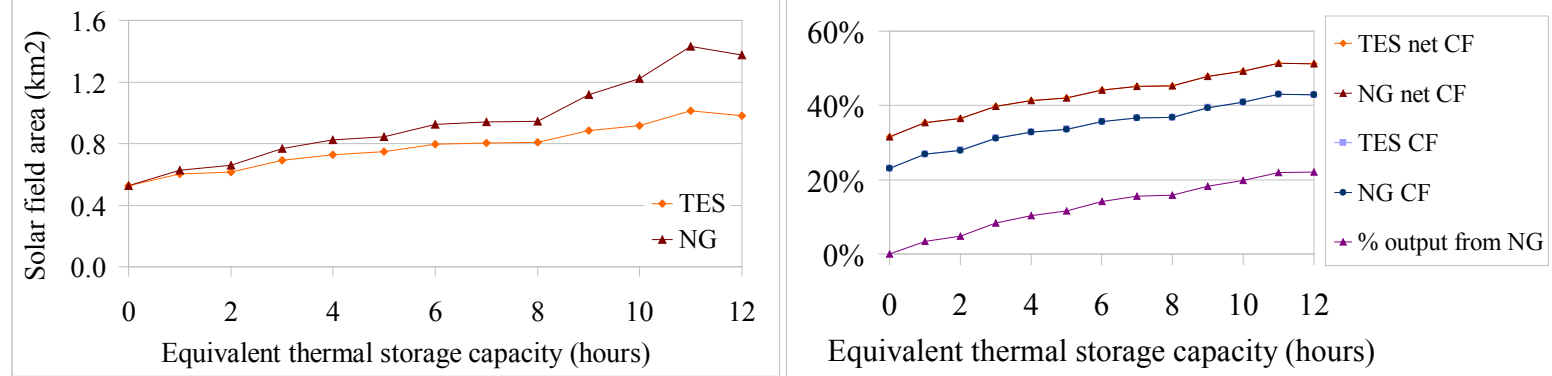

Fig. 2. Solar Field Area (left) and Plant Capacity Factor (right).

The first graph shows the solar field area selected for PT-TES to minimize LCOE and the area selected for PT-NG to match PT-TES electricity output. The second graph shows the corresponding plant capacity factors and the percent of output from natural gas in the PT-NG plant.

Figure 3 shows that the capital costs increased for both plants with increasing equivalent storage capacity, as a larger solar field was required. PT-TES with $1 \mathrm{hr}$ TES had slightly lower capital costs than PT-NG as the latter required a slightly larger solar field. PT-TES with 3-12 hrs TES had higher capital costs than PT-NG as the cost of the TES system outweighed the larger solar field area required by PT-NG. O\&M costs increased with storage capacity, as a larger solar field required more workers and maintenance. The O\&M costs were higher for PT-NG because of the additional annual fuel purchase.
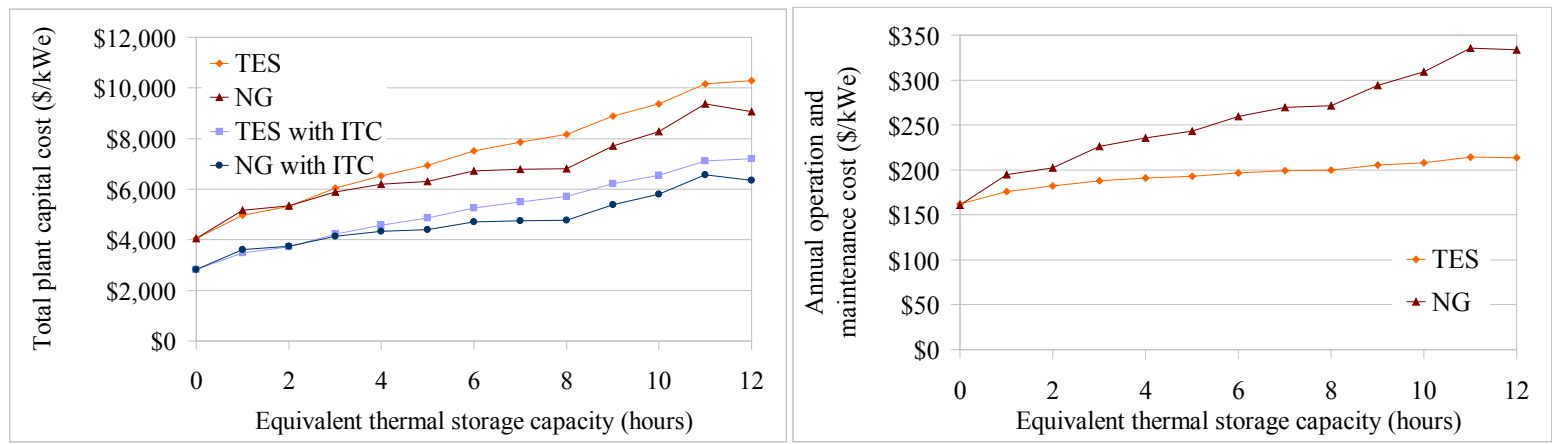

Fig. 3. Total Plant Capital Cost (left) and Annual Operation and Maintenance Cost (right). 
The first graph shows the total plant capital cost for each plant with and without the 30\% investment tax credit (cash grant). The second graph shows the annual O\&M costs for each plant. Assumptions: natural gas $=$ \$US 5.92/MMBtu, auxiliary electricity $=$ \$US 135.15/MWh.

In Figure 4, the LCOE generally increased with storage capacity, and the LCOE of PT-NG varied $+/-6 \%$ from the LCOE of PT -TES. With smaller storage capacities, higher PT-NG O\&M costs outweigh higher PT-TES capital costs to result in lower PT-TES LCOE. With higher storage capacities, higher PT-TES capital costs outweigh higher PT-NG O\&M costs to result in higher PT-TES LCOE. This second effect was lessened with the ITC as the high PTTES capital cost decreased, but the high PT-NG O\&M cost remained unchanged. Based on these costs, a carbon price of \$US 153-\$383/tonne $\mathrm{CO}_{2}$ eq would be required for PT to be competitive with coal, depending on plant specifications.
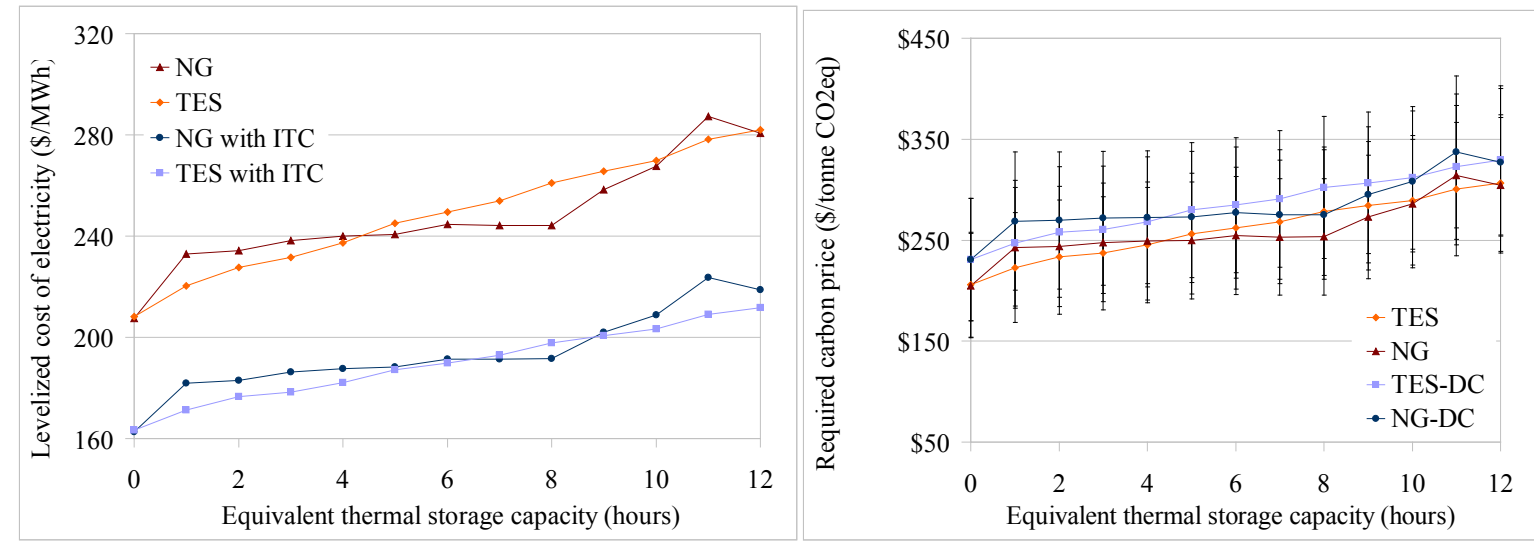

Fig. 4. Levelized Cost of Electricity (left) and Required Carbon Price (right).

The first graph shows the LCOE of each plant with and without the ITC. Assumptions: $k=7 \%, j=20$ years, $F_{\text {debt }}=60 \%, F_{\text {equity }}=40 \%, i=12 \%, n=30$ years. The second graph shows the carbon price that would be required for these plants to be competitive with coal electricity generation in the United States. Assumptions: coal LCOE $=\$$ US 64-74/MWh [9], coal greenhouse gas (GHG) emissions $=0.84-$ 0.88 tonnes/MWh [10], and PT GHG emissions = 0.01-0.185 tonnes/MWh [11]. The bars represent the range of results associated with GHG emission and coal cost bounds.

Figure 5 shows that expected annual profit decreased with increasing storage capacity, and the only scenario that achieved positive annual profit was PPA/ITC with $0-8 \mathrm{hrs}$ TES equivalent, highlighting the importance of guaranteed pricing and financial incentives. Hourly CAISO pricing with no ITC resulted in the largest annual loss, and similar trends were observed across storage capacities as those seen in the LCOE results: PT-TES was more profitable than PT-NG at storage capacities of 1-4 \& $11 \mathrm{hr}$ with no ITC, and 1-6 \& 9-12 hr with the ITC. At the extremes, the profit of PT-NG with PPA/ITC was 4 times greater than $8 \mathrm{hr}$ PT-TES and three times less than $11 \mathrm{hr}$ PT-TES.

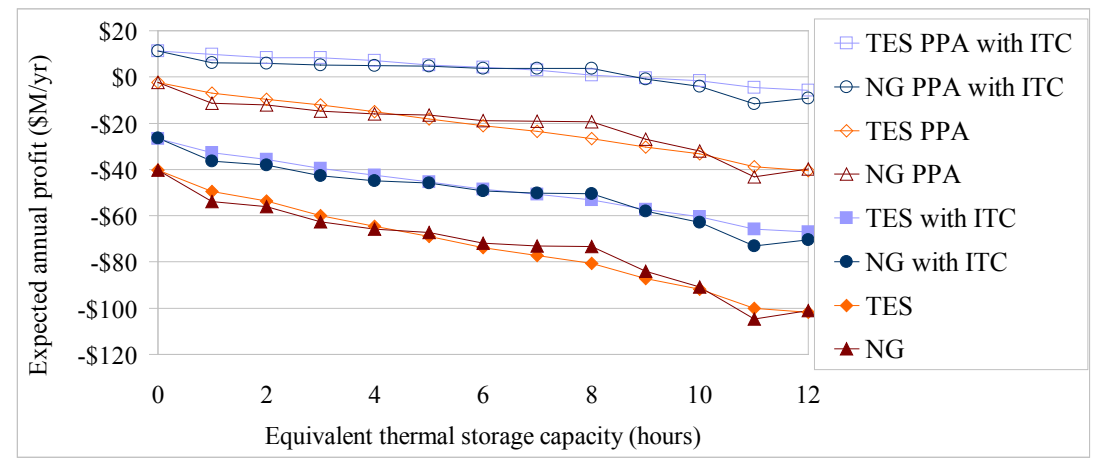


Fig. 5. Expected Annual Profit.

This graph shows the expected annual profit for each plant, using the unsubsidized LCOE, the subsidized LCOE (with ITC), hourly electricity pricing, and power purchase agreement pricing (PPA of \$US 200/MWh).

\section{Discussion and Conclusions}

The results of this analysis are subject to the specific assumptions and calculations outlined above. The uncertainty inherent in these assumptions and the sensitivity of results to changes in nominal values has not yet been explored, but is the subject of future analysis. Nonetheless, the limited scope presented here offers some insights for solar energy policy. Encouraging PT power plants to serve as baseload generators could result in cost increases and profit decreases, whether the additional generation is met by NG or TES. However, a small amount of TES (1-4 hours) is likely to be slightly more profitable and less costly than attempting to achieve similar annual generation with NG backup. If the policy goal is to encourage the deployment of PT power plants as baseload generators, incentives such as the U.S. federal $30 \%$ investment tax credit (ITC) or a generous power purchase agreement (PPA) are necessary to reduce the LCOE and result in a positive expected annual profit. The ITC favors TES compared to NG because it reduces the high TES capital cost but does not affect the high NG O\&M costs. A price of \$US 153 per tonne $\mathrm{CO}_{2}$ eq or higher could make PT competitive with coal electricity generation.

\section{References}

[1] Wilcox, S. and W. Marion. 2008. User's Manual for TMY3 Data Sets, NREL/TP-58143156. April 2008. Golden, Colorado: National Renewable Energy Laboratory.

[2] Price, H., ed. Assessment of Parabolic Trough and Power Tower Solar Technology Cost and Performance Forecasts. Rep.No. SL 5641. Sargent \& Lundy LLC Consulting Group. Chicago, IL: NREL, 2003.

[3] Kreith, Frank, and D. Yogi Goswami, eds. Handbook of Energy Efficiency and Renewable Energy. New York: C R C LLC, 2007

[4] Estimated value from: Kelly, B. and Kearney, D. Thermal Storage Commercial Plant Design Study for a 2-tank Indirect Molten Salt System. Final Report, May 13, 2002 December 31, 2004. Golden, CO.: National Renewable Energy Laboratory (2006).

[5] National Renewable Energy Laboratory, Solar Advisor Model User Manual, 2009

[6] National Renewable Energy Laboratory, Solar Advisor Model Reference Manual for CSP Trough Systems, 2009

[7] Turchi, C. Parabolic Trough Reference Plant for Cost Modeling with the Solar Advisor Model (SAM), National Renewable Energy Laboratory Technical Report No. NREL/TP550-47605, July 2010.

[8] California ISO, version 5.7.7, http://oasis.caiso.com, accessed October 15, 2010.

[9] Integrated Environmental Control Model 6.2.4 (with advanced features selected), http://www.netl.doe.gov/technologies/coalpower/ewr/pubs/cmu-iecm.html.

[10] Jaramillo, P., W.M. Griffin, and H.S. Matthews. 2007. C omparative life cycle air emissions of coal, domestic natural gas, and SNG for electricity generation. Environmental Science \& Technology. 41(17):6290-6296. 
[11]Lechón, Y., C. de la Rúa, and R. Sáez. 2008. Life cycle environmental impacts of electricity production by solarthermal power plants in Spain. Journal of Solar Energy Engineering. 130. 021012-1-7. 